\title{
Immersed hollow fibres microfiltration (MF) for removing undesirable micro-algae and protecting semi-closed aquaculture basins
}

\author{
J.B. Castaing ${ }^{a, b}$, A. Massé ${ }^{a, *}{ }^{*}$ V. Séchet ${ }^{c}$, N.-E. Sabiri ${ }^{a}$, M. Pontié ${ }^{a}$, J. Haure ${ }^{b}$, P. Jaouen ${ }^{a}$
}

a LUNAM Université, Université de Nantes, CNRS, GEPEA UMR 6144, 37 Bd Université, BP 406, 44602 SaintNazaire, France

${ }^{\mathrm{b}}$ IFREMER, Laboratoire Phycotoxines, Centre de Nantes, BP 21105, 44311 Nantes, France

c IFREMER, Laboratoire Conchylicole des Pays de la Loire, Polder des Champs, Bouin, 85230, France

\author{
*: Corresponding author: Anthony Massé, Tel.: + 33240172615 ; fax: + 332401726 18. ; \\ email address : anthony.masse@univ-nantes.fr
}

\begin{abstract}
:
In this study, an original use of immersed microfiltration membranes (mean pore size equal to $0.2 \mu \mathrm{m}$ ) is investigated for the total removal of toxic dinoflagellates from seawater. Using a membrane autopsy and fouling model approach and the use of fouling indexes (called Pore Blocking Index, Pore Constriction Index and Cake Filtration Index), three dinoflagellate suspensions (Heterocapsa triquetra, Alexandrium minutum and Prorocentrum lima) have been microfiltered in order to study the influence of micro-algal species and its concentrations $(1,000$ and 30,000 cells $/ \mathrm{mL}$ ) on filtration yield and membrane fouling mechanisms. Results showed that all micro-algae have been retained after 180 min of microfiltration. At 30,000 cells $/ \mathrm{mL}$, permeate fluxes declined rapidly and an internal fouling occurred at the beginning of microfiltrations followed by a cake deposition. At 1,000 cells $/ \mathrm{mL}$, flux declined slowly and was mainly due to an internal fouling. For a given micro-algae concentration, the filtration behaviour and fouling behaviour can be very different based on the micro-algae species. The dissolved organic substances and particulate size distribution are important factors affecting internal but also external fouling. SEM analyses and fouling indexes are useful tools, simple to implement, and allow the study of membrane fouling and membrane process optimization.
\end{abstract}

\section{Research highlights :}

Removal of toxic dinoflagellates from seawater using a low energy consumption membrane process. Microfiltration for safe shellfish storage during toxic micro-algae bloom. Retention of $99 \%$ of micro-algae by immersed microfiltration membrane. Understanding of membrane fouling mechanisms to process optimization.

Keywords : Red tide ; Dinoflagellate ; Microfiltration ; Membrane fouling mechanisms ; Semi-closed aquaculture basins 


\section{Introduction}

Harmful Algal Blooms ( $\mathrm{HAB}$ ) and more particularly toxic dinoflagellate blooms regularly contaminate coastal water and cause a lot of adverse impacts already well described in the literature [1-7].

Thus, toxic micro-algae efflorescences regularly expose shellfish farming to sale prohibition.

Many studies relate to the separation of the micro-algae with various membrane processes [8-16] but more especially, a previous study [17] investigated immersed membranes for seawater pre-treatment dedicated to total removal of undesirable micro-algae. In our previous study [17], polysulfone immersed hollow fibers microfiltration (MF) and ultrafiltration (UF) membranes were compared. During these filtrations of $H$. triquetra, the best fluxes were obtained with MF membranes. Dead-end filtration mode was chosen rather than tangential filtration due to its lower specific energetic consumption.

Furthermore, a recent study focusing on MF and UF of marine bloom-forming algae suggests that dead-end, open tank membrane configurations similar to those used for membrane bioreactors (MBR) would be more appropriate than crossflow modules [18]. Also, lowpressure membrane processes, such as UF (dead-end), are effective for treating algae-laden waters [19]. In addition, hollow fiber membranes are especially widely used in MBR for wastewater treatment [20,21] but, for some years, have been used in marine aquaculture field or for seawater pre-treatments [4, 22-33].

Micro-algae are known to cause fouling in MF and UF filtration, which results in higher operating costs related to the increase of trans-membrane pressure and intensification of cleaning procedure. Also, fouling caused by deposition of materials on the surface and/or within the membrane material can be influenced by membranes characteristics (morphology and topography, porosity, charge and wettability), module properties and operating parameters such as trans-membrane pressure or air flow rate [34, 35].

Several studies showed that small particles, colloids and extracellular organic matter such as humic substances, nucleic acids, or polysaccharides arising from cell lysis or secretion increase membrane fouling phenomena (pore-blocking, cake-layer resistance and adsorption mechanisms) [18, 36, 37]. According to Ladner et al., 2010 [18], algal cells themselves play a small role in permeate flux decline whereas the highly fouling fraction was cell-derived material larger than $0.22 \mu \mathrm{m}$.

In the present study, an immersed hollow fiber microfiltration (MF) membrane is investigated in order to supply seawater semi-closed systems, preserve commercial bivalves and maintain their quality during a toxic event. This treated seawater could feed the ponds only during toxic events (around 2-3 months per year). The proposed plant has to supply salubrious water in case of emergency situations (a sudden toxic algal bloom), but also during shellfish storage requiring a moderated flow and whose shellfish quality would be ensured by supplementary feeding in non-toxic micro-algae [38]. Thus, such systems would allow commercial shellfish storage. In addition, this filtration process will also be used to minimise effluent discharges to the environment as reported by Jegatheesan et al., 2007 [39].

Through the microfiltration of three dinoflagellates species, known for causing "red tide" in seawater environment, process performances, limited by fouling, were analysed and discussed with the aim to better understand mechanisms implied in the fouling build-up during microfiltration. In particular, blocking and cake filtration models, specific fouling indexes are defined and used for fouling mechanisms description. Coupled with permeate and feed water characteristics and tools for membrane autopsies, fouling indexes should allow to optimise operating parameters (periodic backwash and cleaning procedure notably) 
and should be very useful to limit operating costs by playing a predictive role on membrane fouling.

The preliminary knowledge of seawater composition, of the behaviour of these components on membrane material and the use of specific fouling indexes, will make it possible to durably develop adapted membrane processes for aquaculture activities.

In a first part, in order to study the influence of particle size, dissolved organic substances and species on microfiltration, blooms of 30,000 cells per millilitre of dinoflagellates were reconstituted by diluting the raw culture with isotonic water. The concentration of 30,000 cells per millilitre corresponds to an important natural bloom, although much higher concentrations have already been observed for these species, as reported by Lindholm and Nummelin, 1999, and Pitcher et al., 2007 [40, 41]. Also, A. minutum and H. triquetra are known to reach very high concentrations during algal blooms $\left(>10^{3}\right.$ cells. $\left.\mathrm{mL}^{-1}\right)[40,42]$.

In a second part, in order to study a more current bloom concentration of dinoflagellate, 1,000 cells per millilitre of $A$. minutum is also microfiltered.

Filtration theory in dead-end filtration at constant pressure, in particular from Poiseuille's law, allows to distinguish many models such as blocking models and cake filtration models. Hermans and Bredée, 1936 [43], and Hermia, 1982 [44], were the first to propose four models to explain membrane fouling. The general law used to explain blocking models and thus to identify the filtration mechanism of membrane filtration is given by the relation between the volume second and first derivatives of $t$.

$$
\frac{d^{2} t}{d V^{2}}=k\left(\frac{d t}{d V}\right)^{n}
$$

In the Eq. (1), $k$, the hydraulic resistance coefficient, is a constant and $n$, the blocking index, can take different values according to the fouling mechanisms involved. So, $n$ equals 0,1 , $3 / 2$ and 2 to define respectively cake, intermediate, standard and complete blocking filtration.

Finally, fouling appears to be a surface and/or an internal phenomenon. Concerning internal fouling, it is possible to summarize these mechanisms by two models: standard blocking model (also called pore constriction) and pore blocking model. Standard blocking model assumes that fouling occurs along the pore walls, causing the pore diameter to decrease, while pore density remains constant. Blocking model assumes that the number of pores that become plugged increases proportionally to filtrate volume. In this case, pore diameter remains constant.

In the present study, these models are used in the same way in order to determine which type of fouling mechanism predominantly occurs and causes flow decrease during microfiltration operation. In addition, transition mechanisms (such as intermediate blocking with $n=1$ ) are not investigated in order to analyse the filtration in successive apparent steps during which only blocking mechanisms or cake filtration are predominant. Fouling Indexes presented below are obtained from Hermia's model (Eq. (1)) and the details of the integrations can be found in Hermia, 1982 [44].

According to Hermia's model with $n=3 / 2$, we can define a new fouling index, denoted $P C I$ for "Pore Constriction Index" equal to $(k / 2) \cdot Q_{0}{ }^{-1 / 2}$, representative of standard blocking and defined as the gradient of the linear region found in the plot of $t / V$ versus $t$. $\mathrm{PCl}$ is expressed as $\mathrm{m}^{-3}$. The details of integration can be found in Hermia, 1982 [44]: 


$$
\frac{t}{V}=\frac{1}{Q_{0}}+P C I . t \quad \text { with } \quad P C I=\frac{4 C_{S B M}}{A N_{0} \pi d_{0}^{2} l}
$$

with $Q_{0}\left(m^{3} \cdot s^{-1}\right)$ the initial flow rate, $V\left(m^{3}\right)$, the accumulated permeate volume, $t(\mathrm{~s})$, the filtration time, $C_{S B M}$ the compound volume per unit filtrate volume that deposits onto the pore walls, $N_{0}$ the number of pores per membrane surface area, $A$ the membrane surface area $\left(\mathrm{m}^{2}\right), d_{0}(\mathrm{~m})$ the pore diameter and $/(\mathrm{m})$ the pore length.

According to Hermia model with $n=2$,, we can define a new specific fouling index, denoted $P B I$ for "Pore Blocking Index" equal to $k$ from the Hermia's model and expressed as $s^{-1}$, defined as the gradient of the linear region found in the plot of $Q$ versus $V$ :

$$
Q=Q_{0}-P B I . V \quad \text { with } \quad P B I=\frac{\pi d_{0}^{4} \Delta P A C_{P B M}}{128 \mu l}
$$

with $C_{P B M}$ the number of pores per unit membrane surface area that becomes plugged per unit filtrate volume, $\Delta P(\mathrm{~Pa})$ the applied transmembrane pressure and $\mu(P a . s)$ the solution viscosity.

Surface fouling is evaluated by cake filtration model. A Modified Fouling Index (denoted MFI) was first defined by Schippers and Verdouw, 1980 [45], in order to evaluate particles fouling potential of water by a cake filtration model. Since then, other authors have regularly used this index [46-48] instead of SDI [49] widely used in water process engineering [50-55]. In the present study, MFI is renamed CFI for "Cake Filtration Index". We considered CFI more explicit, in this study, to designate the type of cake fouling. CFI defined as the gradient of the linear region found in the plot of $t / V$ versus $V$ (Eq. (4). So, CFI allows evaluation of cake fouling intensity during dead-end filtration at constant transmembrane pressure. Also, CFI is equal to $\mathrm{k} / 2$ with $n=0$ from the Hermia's model and is expressed as $\mathrm{s} . \mathrm{m}^{-3}$.

$$
\frac{t}{V}=\frac{1}{Q_{0}}+C F I . V \text { with } \quad C F I=\frac{\mu C_{b} \alpha}{2 \Delta P A^{2}}
$$

As shown by the previous equation (Eq.(4)), CFI is linked to the applied transmembrane pressure $(\Delta P)$, the dynamic viscosity of permeate $(\mu)$, the specific resistance of deposited cake $(\alpha)\left(\mathrm{m} \mathrm{kg}^{-1}\right)$ and the mass of dry cake per volume of permeate $\left(C_{b}\right)\left(\mathrm{kg} \cdot \mathrm{m}^{-3}\right)$.

Thus the slope of $t / V$ versus $V$ curve allows to determine $C F I$ values.

This approach to determine the different fouling mechanisms during membrane filtration has already been chosen in some studies concerning dead-end MF $[56,57]$. In our case, we engage the same approach by assuming that our immersed hollow fiber MF operation is considered equivalent to dead-end filtration.

\section{Material and methods}

\subsection{Pilot plant description}

The surface membrane area was equal to $0.37 \mathrm{~m}^{2}$ (table 1 ). The pure water permeability determined at $20^{\circ} \mathrm{C}$ was equal to $511 \pm 62 \mathrm{~L} \cdot \mathrm{h}^{-1} \cdot \mathrm{m}^{-2} \cdot \mathrm{bar}^{-1}$. Initial membrane roughness values ranged from 160 to $260 \mathrm{~nm}$ in an area of $50 \times 50 \mu \mathrm{m}$. Air was injected at $676 \mathrm{~L} . \mathrm{h}^{-1} \cdot \mathrm{m}^{-2}$ through a porous medium at the bottom of membrane module. Shear stress induced by bubbles on membrane surface and fibre movement contributes to prevent fouling. No backpulses were performed during the experiments except at the end of the runs (10 
seconds with a pressure equal to 1 bar) in order to measure irreversible fouling (defined as the part of fouling not removable by backwashes but only by chemical cleanings).

Fig. 1 shows a schematic diagram of the laboratory pilot plant.

The membrane bundle (lab scale unit) was placed in a tank containing 40 litres of reconstituted seawater prepared from deionised water $(\mathrm{pH}=7.3, \mathrm{TOC}<1 \mathrm{ppm}$ and conductivity $=0.76 \mu \mathrm{S} / \mathrm{cm}$ ) adjusted at $35 \mathrm{~g} / \mathrm{L}$ with $\mathrm{NaCl}$ enriched with the micro-algae suspension to be filtered. A microfiltration polysulfone hollow-fibre membrane of $0.2 \mu \mathrm{m}$ pore size (Polymem) was used. Membrane characteristics are shown in Table 1.

All microfiltrations were operated at constant transmembrane pressure (0.3 bar). From permeate flux recording, the total fouling resistance $\left(R_{f}\right)$ was determined according to Darcy's law (Eq. (5)):

$$
J=\frac{Q}{A}=\frac{1}{A} \frac{d V}{d t}=\frac{\Delta P}{\mu\left(R_{m}+R_{f}\right)}
$$

with, $J$, the permeate flow $\left(\mathrm{m}^{3} \cdot \mathrm{s}^{-1} \cdot \mathrm{m}^{-2}\right), R_{m}$, the membrane resistance $\left(\mathrm{m}^{-1}\right)$ and $R_{f}$, the total fouling resistance $\left(\mathrm{m}^{-1}\right)$.

In accordance with membrane supplier instructions, the membranes have been chemically cleaned in three successive stages: $1 \mathrm{~h}$ bath with $200 \mathrm{ppm}$ of hydroxyde sodium, $1 \mathrm{~h}$ with 50 ppm of oxalic acid and 4h with 200 ppm of chlorine solution. Before each bath, rinsing was carried out using deionised water. All solutions were prepared from deionised water $(\mathrm{pH}=$ 7.3 , TOC $<1 \mathrm{ppm}$ and conductivity $=0.76 \mu \mathrm{S} / \mathrm{cm}$ ).

Cleaning procedure was carried out before each filtration. After membrane fouling, the cleaning procedure was repeated until the recovering of the initial permeability.

During microfiltration of micro-algae suspensions, the mean permeate was sampled in order to evaluate the retention rate $R R$ calculated from the following equation:

$$
\text { (6) }=1-\frac{C_{p}}{C_{f}}
$$

with $C_{p}$, the concentration in the permeate at the end of filtration and $C_{f}$, the concentration in feed water.

\subsection{Micro-algae suspensions}

Three dinoflagellates species were used in this study. Reconstituted blooms characteristics are shown in Table 2 and micro-algae images are shown in Fig. 2.

Prorocentrum lima (Ehrenberg, 1860 - Stein, 1975) (strain PL4V) is an epiphytic-benthic dinoflagellate responsible for Diarrhetic Shellfish Poisoning (DSP) in consumers. Cells are generally oblong to ovate in shape and their length varies from 30 to $50 \mu \mathrm{m}$ and their width from 25 to $30 \mu \mathrm{m}$ [58]. P. lima was cultured in "f/2 medium" [59] without silica addition, in $10 \mathrm{~L}$ tanks bioreactor. 
Alexandrium minutum (Halim, 1960) (strain AMBM89), is a pelagic dinoflagellate responsible for Paralytic shellfish poisoning (PSP) and one of the smallest toxic dinoflagellate observed during toxic blooms in French coastal waters. Cells are small, rounded and slightly longer than wide, around $20-25 \mu \mathrm{m}$ long and $20-24 \mu \mathrm{m}$ wide $[41,60,61]$. A. minutum was cultured in "L1 medium" [62] in a $100 \mathrm{~L}$ tank bioreactor. In the case of continuous flow cultures in bioreactor, we observed a decrease in cell size down to $12 \mu \mathrm{m}$ [63].

Heterocapsa triquetra (Ehrenberg) Stein 1883 (HT99PZ) is a non-toxic strain pelagic dinoflagellate which has been selected for its morphological and size similarities with $A$. minutum and for its easy handling due to its harmless character. Moreover, A. minutum and $H$. triquetra are naturally co-occurrent species during algal blooms [42, 64]. $H$. triquetra was cultured in "L1 medium" [62] in 10-L tanks bioreactor.

Toxics micro-algae experiments were carried out under adapted safety conditions and compliance in a specialized laboratory.

Particle size distributions of each micro-algae culture are shown in Fig 3. The distribution density $(q)$ expressed as $\mathrm{mm}^{-1}$ represents the normalized particles area fraction $(\Delta Q$, dimensionless) divided by the size of the corresponding interval ( $\Delta x$ expressed as $\mathrm{mm}$ ). These results had been obtained using QICPIC analyser (Sympatec, Clausthal-Zellerfeld Germany). Cultures were directly injected in the analytical cell without specific treatment.

\subsection{Membranes autopsy tools}

Several tools can be used for membrane autopsies as previously reported [47, 65-67].

In the present study, Field Emission Gun Scanning Electron Microscopy (SEM) has been used in order to characterize morphology of cleaned and fouled membrane surfaces. The apparatus used was JSM-6301F from JEOL (SCIAM, Angers University, France). Images obtained were from secondary electrons under 3-5 keV with magnifications comprised between 3000 and 5000. Membrane samples were desiccated and glued to a carbon support. First, samples were washed three times in isotonic ammonium formate solution $(S=35)$. Then, samples were stored with glutaraldehyde solution $(4 \%)$, and progressively dehydrated with alcohol solution (10\% to $100 \%)$ and dried during one night by slow evaporation. The samples were then attached to steel discs with double side scotch tape. Finally, thin film carbon of $2 \mathrm{~nm}$ thickness was deposited by evaporation under a vacuum (BAL-TEC MED 020 Balzers Lichentstein apparatus).

Hollow fibres have always been sampled at the same place (in the middle of the fibers), before and after fouling and also after cleaning.

Pores size and pores density on membrane surface were measured by computer-assisted image analysis (OPTIMAS 6.51, Media Cybernetics).

\subsubsection{Contact angle measurements}

The contact angle measurements were made by the sessile drop technique: a liquid droplet is placed on a flat homogeneous surface and the contact angle of the droplet with the surface is measured with a KRUSS DS10 contact angle meter. The contact angle measurements were made on dried membrane samples on both hollow fiber membrane sides: ouside and inside. A droplet of MilliQ water solution ( $\mathrm{pH}$ 6.5) and a volume of $100 \mathrm{~nL}$ was deposited on the surface using a micro-syringe and a camera measured the angles during the first second after water droplet deposition. Reported values are the averages of the contact angles (right and left) of three droplets. 


\subsubsection{Roughness analysis by AFM}

The AFM (Atomic Force Microscopy) analyses were conducted with a Nanoscope III device from Veeco (USA). The membrane morphologies were imaged in contact mode in air with a scan rate of $1 \mathrm{~Hz}$ and $400 \times 400$ pixel resolution. The cantilevers used for such imaging were from Veeco (Dourdan, France), with a specified spring constant between $0.44-0.63 \mathrm{nN}$ and a resonant frequency of $17-20 \mathrm{kHz}$. The mean roughness (denoted $R_{a}$ ) is the mean distance from surface to the centre plane and is calculated in the following equation:

$$
R_{a}=\frac{1}{L x L y} \int^{L x} \int^{L y}[f(x, y)] d x d y
$$

where $f(x, y)$ is the surface relative to the centre plane and $L_{x}$ and $L_{y}$ are the dimensions of the analyzed surface. The same cantilever was used for all AFM images and all the AFM treated in this way. The membrane samples were dried at room temperature in a desiccator. The samples were then attached to steel discs with double-side scotch tape. The images were obtained over the area $50 \mu \mathrm{m} \times 50 \mu \mathrm{m}$.

Image analysis was carried out by means of (SPMLab602) software from Veeco (France). We focused our attention on $R_{a}$ values only for virgin membrane. In the present study $R_{a}$ values are resulting from two field analyses on each sample using contact analysis mode. For $R_{a}$, the values reported are the average values of two fields analysed (size $50 \mu \mathrm{m} \times 50$ $\mu \mathrm{m})$.

\subsection{Water analytical methods}

Total Organic Carbon (TOC) and Dissolved Organic Carbon (DOC) concentrations were measured by high temperature combustion on a Shimadzu TOC 5000 Analyser according to the analytical procedure described by Cauwet, 1999 [68]. DOC samples were collected in glass tubes and were obtained by filtering the TOC sample through a glass fibre filter (Whatman GF/F, $0.7 \mu \mathrm{m}$ ). All glass vessels and glass fibre filters were rinsed with Milli-Qwater and then combusted during $6 \mathrm{~h}$ at $450^{\circ} \mathrm{C}$ prior utilization to remove organic contaminants $[69,70]$.

Total suspended solid analyses were performed using glass fibre filter GF/F.

The turbidity measurement was carried out with a Hach 2100AN IS turbidimeter.

Cell concentrations was determined from cell counts in a Nageotte haemocytometer chamber under a photonic microscope, with a Coulter Counter Multisizer particle analyser (Beckman-Coulter) and with a QICPIC particle analyser using image analysis (Sympatec, Clausthal-Zellerfeld Germany). 


\section{Results and discussion}

\subsection{Influence of particles size, dissolved organic substances and species on microfiltration performances}

\subsubsection{Selectivity and hydraulic performances}

Selectivity and hydraulic performances are fundamental criteria to evaluate membrane treatment effectiveness.

Average rejection rates during MF are reported on Table 3.

As aimed in this study, all micro-algal species are retained by the process (RR $>99 \%$ ). Due to an analytical error estimated to $1 \%$, RR is not equal to $100 \%$ but no micro-algae were found in all the permeates during our experiments. These results are consistent with a previous study already carried out with the micro-alga $H$. triquetra [17]. So, the permeate is a clarified seawater (turbidity $<0.2$ NTU and $S=35$ ) more or less charged in organic DOC with $12.2 \pm 0.8 \mathrm{mgC} / \mathrm{L}, 4.9 \pm 0.3 \mathrm{mgC} / \mathrm{L}$ and $3.3 \pm 0.1 \mathrm{mgC} / \mathrm{L}$ respectively for $P$. lima, $A$. minutum and $H$. triquetra. The higher retention rates for DOC is obtained from P.lima permeate with $46 \%$. The nature of DOC has not yet been elucidated: it can be attributed to mucilage, exudates or intracellular material from microfiltered micro-algae. According to many studies $[18,71]$, DOC can be attributed to the macromolecular components and extracellular polymeric substances mainly composed of polysaccharides, nucleic acids and proteins.

Fig. 4 shows the relative flux versus time microfiltration curves for each micro-algae suspension. Each curve can be divided into two regions. At the beginning of filtration, flow rate rapidly decreases and then slowly declines down to a pseudo-steady state. At pseudosteady state, the permeate fluxes are equal to $15 \pm 1 \mathrm{~L} \cdot \mathrm{h}^{-1} \cdot \mathrm{m}^{-2}$ for $P$. lima and $A$. minutum microfiltration and to $27 \pm 1 \mathrm{~L} . \mathrm{h}^{-1} \cdot \mathrm{m}^{-2}$ for $H$. triquetra microfiltration.

Fluxes permeate data and permeate compositions indicate in particular that micro-algae are totally retained by the process and that DOC is partially retained on MF membrane, especially for the $A$. minutum and $P$. lima MF. At the end of the MF operation, it appears that $A$. minutum and $P$. lima are responsible for highest fluxes decline, although fluxes are similar at the beginning of MF for $H$. triquetra and $A$. minutum. This seems to indicate that fouling mechanisms are different for each case.

\subsubsection{Fouling indexes determination}

Fig. 5 shows the fouling resistance versus filtration time for each MF during the first hour of microfiltration. Resistance curves increase with an increasing slope to a point of inflexion located between $\mathrm{t}=10 \mathrm{~min}$ and $\mathrm{t}=20 \mathrm{~min}$ and then slowly increase with a decreasing slope. This zone located in the first 20 minutes is also observed in Fig. 4 where fluxes rapidly decrease. Indeed, the permeate fluxes lose $78 \%, 62 \%$ and $55 \%$ for $P$. lima, A. minutum and $H$. triquetra microfiltration respectively in the first 20 minutes, while part of total fouling resistance only accounts for $28 \%, 14 \%$ and $22 \%$ for $P$. lima, $A$. minutum and $H$. triquetra microfiltration respectively.

It was already shown that a plot of total resistance versus time is concave upward when $n>$ 1 ( $n$ from Hermia's equation (Eq. (1))) and concave downward when $n \leq 1$ [56]. Furthermore, as observed in this same study, it is advisable to choose a period of time during which effects of membrane compaction and the lag in permeate delivery for short time and cake formation for long times are not included. Thus, it is consistent in our case to choose the period of time 
from 5 to 20 minutes for linear regression in order to determine PBI (Eq. (3)) and PCI (Eq. (2)).

Other studies concerning "dead-end" microfiltration have already shown that standard and pore blocking mainly occurred at the first stage of microfiltration and that cake filtration mainly occurred in a second phase $[56,72-77]$.

Fig. $6 \mathrm{a}$ and Fig. 6b show $t / V$ versus time MF curves (Standard blocking model) and $Q$ versus $\checkmark$ MF curves (Pore blocking model) respectively for each micro-algae suspension microfiltered. Values for $\mathrm{PBI}$ and $\mathrm{PCl}$ determined from the slopes for the period of time from 5 to 20 minutes are given in Table 4 . $\mathrm{PCl}$ values show a standard blocking pore mechanism in the same range for $H$. triquetra and $A$. minutum microfiltration with $0.028 \mathrm{~L}^{-1}$. However, $P$. lima microfiltration shows the highest value with $0.055 \mathrm{~L}^{-1}$. The same tendency is observed concerning the $\mathrm{PBI}$ values with $3.2 \mathrm{~h}^{-1}$ and $3.6 \mathrm{~h}^{-1}$ for $H$. triquetra and $A$. minutum microfiltration respectively and $5.2 \mathrm{~h}^{-1}$ for $P$. lima microfiltration. This shows that both internal foulings occur in the three cases, but that during the $P$. lima microfiltration these phenomena are more significant. Thus, in this first stage of microfiltration, a decrease in pore diameter and pore density occurred, which induced a rapid decrease of permeate fluxes.

According to the cake filtration theory, the filtration curve can be regressed to a straight line to define the CFI. Based on cake filtration equation, CFI shows the consequence of deposited layer at the membrane surface. Fig. 6c shows the $t / V$ versus $V$ and the linear regression of the data performed from $t=20$ minutes and $t=180$ minutes for each microalgae suspension microfiltered. Indeed, in the manner of relative permeate fluxes curves (Fig. 4), it is possible to distinguish two regions. From $t=0$ to $t=20$ minutes, filtration curves are not linear and then, they change to a straight line to indicate a cake filtration phenomenon. For each CFI determination, a linear correlation higher than $99 \%$ is obtained $\left(r^{2}>0.99\right)$.

CFI values presented in Table 4, show a filtration cake more significant and equivalent for $P$. lima and $A$. minutum microfiltration with 11.4 and $10.3 \mathrm{~s} / \mathrm{L}^{2}$ respectively. As for $H$. triquetra filtration, $\mathrm{CFI}$ is lowest with $3.5 \mathrm{~s} / \mathrm{L}^{2}$.

Consequently, the MF membrane shows the most propensities for internal and surface foulings for $P$. lima filtration, and lowest for $H$.triquetra filtration. On the contrary, $A$. minutum suspension had caused an internal fouling in the same range as $H$. triquetra and a surface fouling in the same range as P.lima.

These differences of MF behaviour can be attributed to the differences of DOC and particulates concentration measured in feed waters. Indeed, according to the filtration theory and some authors' reports [57, 76], internal fouling occurred if particles, macromolecules and colloidal materials, smaller or comparable in size with pores diameter, can be captured in the selective layer thickness or in the membrane matrix by adsorption phenomenon to the pore walls or by physical blocking.

Moreover, these compounds, responsible for internal fouling, can also cause the formation of a cake layer. On the contrary, if the water compounds are larger than the pore size, only surface fouling can arise.

Concerning $P$. lima microfiltration, high propensity to cause significant pore blocking and standard pore fouling can be explained by the following assumption: $P$. lima is known to exude high quantity of mucilage from its epiphytic mode of life and $P$. lima cultures have the higher values of DOC. Blended with high concentration in fine particles (smaller than MF mean pore diameter), DOC contents, composed primarily of dissolved living matter and exopolymeric substance (EPS) (exopolysaccharides, proteins, lipids, humic substances,...) 
and subject to cause internal fouling, can explain why $P$. lima causes the higher blocking and standard pore fouling for the membrane study.

However, concerning cake formation, $A$. minutum and $P$. lima present very close CFI values (10.3 and $11.4 \mathrm{~s} / \mathrm{L}^{2}$ respectively) despite a bigger cell size for $P$.lima than $A$. minutum. So, according to Eq. (4), $C_{b-P . l i m a} \cdot \alpha_{P . \text { lima }}$ is almost equal to $C_{b \text {-A.minutum }} \cdot \alpha_{A \text {.minutum. }}$ For the present study, $C_{b-P . l i m a}$ is superior to $C_{b-A \text {.minutum }}$ with $C_{b}$ estimated by TSS values ( TSS $_{P \text {.lima }}=258.5$ $\mathrm{Kg} / \mathrm{m}^{3}$ and $\left.\mathrm{TSS}_{\text {A.minutum }}=47.2 \mathrm{Kg} / \mathrm{m}^{3}\right)$, and the specific cake resistance $(\alpha)$ for $P$.lima is lower than for $A$. minutum $\left(\alpha_{A \text {. minutum }}=1.39 \times 10^{12} \mathrm{~m} / \mathrm{Kg}\right.$ and $\left.\alpha_{P . \text { lima }}=2.71 \times 10^{11} \mathrm{~m} / \mathrm{Kg}\right)$.

CFI obtained for $A$. minutum is higher than $H$. triquetra (3.5 versus $10.3 \mathrm{~s} / \mathrm{L}^{2}$ ). This difference could be explained by a more compact cake from $A$. minutum due to higher value in TSS, DOC and a larger particle size distribution with the existence of fine particles despite its slightly larger mean diameter compared to $H$. triquetra suspension. Thus, $\mathrm{CFI}_{\text {A.minutum }}>$ $\mathrm{CFI}_{\text {H.triquetra }}$ because $C_{\text {b-A.minutum }} \cdot \alpha_{\text {A.minutum }}>C_{\text {b-H.triquetra }} \cdot \alpha_{\text {H.triquetra }}$ with $\alpha_{\text {H.triquetra }}=9.45 \times 10^{11}$ $\mathrm{m} / \mathrm{Kg}$. Furthermore, higher values of DOC and TSS for $A$. minutum compared to $H$. triquetra are measured in the medium when $A$. minutum is operated in semi continuous culture mode. This phenomenon could be due to the presence of elderly cells in the medium with EPS exudation and foam formation.

Concerning $A$. minutum and $H$. triquetra microfiltration, the calculated internal fouling indexes $(\mathrm{PCl}$ and $\mathrm{PBI}$ ) are in the same range (Table 4). This can notably be explained by close DOC values for these two species suspensions with $6.3 \pm 1.3 \mathrm{mgC} / \mathrm{L}$ and $3.3 \pm 0.2 \mathrm{mgC} / \mathrm{L}$ for $A$. minutum and $H$. triquetra respectively. Indeed, $A$. minutum and $H$. triquetra are both pelagic dinoflagellates and thus are not susceptible to exude large quantities of mucilage in the manner of $P$. lima with a DOC value equal to $22.7 \pm 3.0 \mathrm{mgC} / \mathrm{L}$.

These results indicated that microalgae sizes and their mean diameters are not only parameters for determining fouling behaviour. Indeed, according to species, microalgae may have a deformable structure even under low pressure and may exude various amounts of EPS which can also be very different in nature. These substances may be more or less fragile and, in the case of cells breakage, induce a high quantity of fine particles in the medium, smaller than membrane pore diameter. EPS, fine particles and deformable cells could, alone or associated, contribute to internal fouling and/or a cake formation.

To conclude, it seems that internal fouling (pore blocking and pore constriction) would be mainly due to dissolved organic substances and cake filtration due to particles. Fine particles, alone or blended with dissolved organic substance, could be responsible for high value of specific cake resistance because of their ability to fill the void spaces between the micro-algae. In addition, a previous study using a fractal permeation model to study the mechanism of membrane fouling [78] allowed to describe these phenomena. Indeed, as already shown, particle size distribution and macromolecules are important factors affecting cake layer permeability $[78,79]$. Furthermore, in the microfiltration process, bigger particles can easily back-transport from the cake layer into the bulk due to the shear force, and the smaller particles may be captured by viscous substance such as protein, carbohydrate and so on, and cause more severe membrane fouling [78]. In addition, it has already been shown [77] that complete blocking and standard blocking are promoted when microfiltration is operated under low and constant pressure (<1 bar) as presently reported.

\subsubsection{Scanning Electron Microscopy experiments}

After 180 minutes of microfiltration, a backwash is operated from permeate under a pressure of 1 bar during 10 seconds. A permeation flux is then measured in pure water. If we consider that residual fouling corresponds to irreversible fouling, it appears that reversible fouling is responsible for $31 \%, 18 \%$ and $35 \%$ of total flow loss caused by total fouling for $P$. lima, $A$. minutum and $H$. triquetra respectively. This indicates that irreversible fouling represents the 
main contribution to fouling. In order to observe the surface morphology of membrane with irreversible fouling, SEM analyses are carried out.

As in a previous study [17], SEM analyses result from samples of membrane fibres with a specific preparation and not from in situ membrane observation. Fig. 7 shows the clean MF membrane and Fig. 8 shows SEM images of MF after 180 minutes of filtration and backwash for $P$. lima and $H$. triquetra microfiltration.

Fig. 7 shows that $0.2 \mu \mathrm{m}$ membrane presents a mean diameter ranging from 0.03 to $1.68 \mu \mathrm{m}$ and a pores density approximately equal to $4.25 \times 10^{11}$ pores $/ \mathrm{m}^{2}$.

Concerning fouled membranes (Fig. 8), it appears clearly that a majority of pores are not visible anymore due to the presence of various particles of different shapes and sizes blended with an organic matrix. Concerning $H$. triquetra microfiltration (Fig. 8 a), the layer is relatively porous contrary to that observed for $P$. lima microfiltration (Fig. $8 b$ ), which seems thicker and more dense with many particles and aggregates covering the membrane surface. Linked with low values of TSS and COD content, this could explain why the flow is less limited for $H$. triquetra. Also, Jaouen et al., 1999 [8] and Rossignol et al., 1999 [15], have already attributed pore clogging and internal fouling in MF caused by a progressive penetration in the membrane pores (around $0.2 \mu \mathrm{m}$ ) of small particles of equivalent size (cell fragments) and some dissolved macromolecules.

Furthermore, contact angle measured on membrane fouled by $H$. triquetra suspension shows an increase in the hydrophilicity of the membrane outside and inside surface (inside surface evaluated at $7 \pm 1^{\circ}$ versus $32 \pm 11^{\circ}$ for the clean membrane, outside surface membrane evaluated at $17 \pm 4^{\circ}$ versus $28 \pm 5^{\circ}$ for the clean membrane). These measurements are consistent with an internal and an external organic fouling, which can be linked to the high adsorption potential of macromolecules (i.e. EPS suspected before) as already underlined by previous studies [9-12, 80]. These results indicate that the more significant irreversible fouling is, the faster reversible cake establishment will be and consequently a drastic drop of flux will be observed during the $P$. lima microfiltration. In order to prevent the drop of permeability, a solution could be to promote the formation of a filtration cake at the beginning of filtration in order to prevent pore density and pore diameter reductions on the membrane surface, and finally limit severe internal fouling. Furthermore, as explained by Frappart et al. 2010 [81], irreversible fouling might also be limited by reducing EPS synthesis from microalgae suspension, which is reduced by limiting yield stress and impact of hydrodynamics generated by the process.

In addition, the absence of micro-algae on membrane surfaces suggests that no strong affinities exist between micro-algae and membrane surface, as recently reported [17]. This agrees with the fact that micro-algae mainly lead to cake formation, causing reversible fouling, and that SEM observations represent an irreversible fouling mainly caused by pore blockage and pore constriction mechanisms. Furthermore, according to Kennedy et al., 1998 [82], irreversible fouling is generally caused by pore blocking or adsorption phenomenon. This consolidates our conclusion from filtration models. SEM images show some particles smaller than pore diameter at the membrane surface (Fig 8). These compounds could participate to the internal membrane fouling.

As suggested by other studies [73, 77,83$]$, these models might coexist during microfiltration within transition mechanisms from pore blocking to cake filtration. Thus, this study confirms this observation and reveals that membrane pores, accessible in the first stage of microfiltration, can undergo internal fouling (standard and pore blocking mechanisms) to result in a decrease of pore diameter and pore density, and finally in a cake layer formation, increase of fouling resistance and decrease of permeate flow. However, fouling models evoked earlier are not perfect and do not take into account, for instance, the co-occurrence of all these phenomena or the fouling heterogeneity on membrane surfaces. To conclude, in order to simplify mechanisms coming into play and thus to better understand these 
phenomena, a schematic diagram is shown in Fig. 9 in order to illustrate all three fouling models (standard blocking, pore blocking and cake filtration).

The scheme in fig. 9 shows that a membrane pore is exposed to two types of internal fouling in the first moments of filtration: the same pore can undergo both phenomena (Standard blocking and pore blocking). Cake formation occurs only afterward, after the possible internal obstruction of the pores.

\subsection{Influence of micro-algae concentration on microfiltration}

In natural condition, it is exceptional to observe $\mathrm{HAB}$ concentration equal to $30,000 \mathrm{cells} / \mathrm{mL}$. 1,000 cells $/ \mathrm{mL}$ is more current and even high (Ifremer/Quadrige database, France). So, in order to compare MF performances obtained for these two dinoflagellate concentrations, an MF operation with 1,000 cells $/ \mathrm{mL}$ was carried out. Cells, turbidity and TSS retention rate obtained were higher than $99 \%$. TOC and DOC values were too low to be significant. So, only hydraulic performances are discussed.

Relative flow rates versus time are shown in Fig. 10 and discussed in the following part.

In 180 minutes of MF, the permeate flux is equal to $108 \pm 5 \mathrm{~L} \cdot \mathrm{h}^{-1} \cdot \mathrm{m}^{-2}$ for 1,000 cells $/ \mathrm{mL} A$. minutum microfiltration, that is sevenfold higher than for the MF with 30,000 cells $/ \mathrm{mL}$. The general curve appearance is also different compared with that obtained with 30,000 Cells $/ \mathrm{mL}$. Indeed, the 1,000 cells $/ \mathrm{mL}$ curve slowly decreases and does not drastically drop like the 30,000 cells/mL curve.

Fouling resistance curve for 1,000 cells $/ \mathrm{mL}$ A. minutum microfiltration is shown in Fig. 11 . During the first 30 minutes of MF, $R_{f}$ does not increase significantly. Then, from this time to the end of MF ( $\mathrm{t}=210$ minutes), $R_{f}$ increases with an increasing slope in the same way as $A$. minutum 30,000 cells $/ \mathrm{mL}$. However, from 180 minutes to 210 minutes, a point of inflexion is noticeable. Following the same reasoning as in the previous section, it is possible to identify standard and pore blocking phenomena during this microfiltration. Thus, indexes $\mathrm{PCl}$ and $P B I$ can be determined during MF from 30 minutes to 180 minutes (Fig. 12): $P C l$ and $P B I$ are equal to $0.002 \mathrm{~L}^{-1}$ and $0.20 \mathrm{~h}^{-1}$, respectively.

For A. minutum 1,000 cells $/ \mathrm{mL}$ microfiltration, no cake filtration phenomenon is identified. So, after 210 minutes of filtration, fouling is essentially due to internal fouling during MF. Contrary to 30,000 cells $/ \mathrm{mL} A$. minutum MF, which causes rapid flow decline and high values of fouling indexes, 1,000 cells $/ \mathrm{mL} A$. minutum MF causes a slow decrease of flow mainly due to a low intensity of internal fouling. In addition, flow observed at 210 minutes is not a steadystate flow and a longer time of filtration should allow a filtration cake to build.

After 210 minutes of filtration, a backwash is operated from permeate under a pressure of 1 bar during 10 seconds and the permeate flow measured in pure water. Considering that residual fouling corresponds to irreversible fouling, it appears that reversible fouling is responsible for $28 \%$ of total flow loss caused by total fouling. As observed before, this indicates that irreversible fouling represents the majority of the fouling deposit in our condition.

The use of specific fouling indexes such as those quoted in the present work (Pore Constriction Index (PCl), Pore Blocking Index (PBI) and Cake Filtration index (CFI)) would make it possible to better apprehend and diagnose fouling deseases encountered during a membrane MF operation.

Indeed, irreversible and internal fouling, mainly caused by fine particles and DOC from microalgae, can be identified using $\mathrm{PBI}$ and $\mathrm{PCl}$, whereas cake filtration can be evaluated 
using CFI. Furthermore, as already demonstrated by Nyström et al., 1996 [84] and more recently by Kecili et al., 2006 [48], DOC can cause a gel layer formation on the membrane surface which causes high values of CFI after several days of filtration. So, the fouling indexes approach will help to identify the type of fouling (internal, cake...) and prevent it.

Furthermore, this approach by fouling mechanisms understanding should allow specific power consumption reduction and physical process optimization, in particular by an adjustment of pre-treatment or an adjustment of operating parameters of the process, such as backwash cycle frequency, backwash duration, trans-membrane pressure, air flow rate or time necessary to clean and regenerate membranes... For instance, on the basis of fouling indexes values, the backwash could begin after the first stage of the filtration, during the internal fouling establishment, in order to avoid a cake filtration phenomenon. Also, the value of trans-membrane pressure of membrane filtration could be selected according to fouling indexes in order to limit fouling phenomena and obtain the best specific energy consumption.

In addition, as shown in some studies [85-89], special attention will be devoted to the shear stress from pumps and valves and membrane process, which could cause micro-algae damage and thus increase of internal fouling caused by small particles and macromolecules from micro-algae.

\section{Conclusion}

This study deals with the technical feasibility to implement submerged polysulfone MF membranes in semi-closed aquaculture systems during algal bloom episodes; membranes must totally retain toxic micro-algae. Three dinoflagellate suspensions of $30,000 \mathrm{cells} / \mathrm{mL}$ have been characterised and then microfiltered.

Retention rate results show that more than $99 \%$ of micro-algae are eliminated by MF membrane. Seawater produced is clarified (turbidity $<0.2 \mathrm{NTU}$ ) with DOC values equal to $12.2 \pm 0.8 \mathrm{mgC} / \mathrm{L}, 4.9 \pm 0.3 \mathrm{mgC} / \mathrm{L}$ and $3.3 \pm 0.1 \mathrm{mgC} / \mathrm{L}$ respectively for $P$. lima, $A$. minutum and $H$. triquetra and can be considered potentially suitable to be used for shellfish storage. The higher retention rates for DOC are obtained from P.lima permeate with $46 \%$.

It appears that fouling is responsible for flux decline, which is all the higher as particulate and DOC concentrations are high, and that pore constriction and pore blocking phenomena, which are mainly responsible for irreversible fouling, occurred mainly in the first stage of MF (from 0 to 20 minutes of filtration in our conditions). DOC can be mainly attributed to EPS from micro-algae.

$\mathrm{PCl}$ and $\mathrm{PBI}$ values are equal to $0.055 \mathrm{~L}^{-1}, 0.028 \mathrm{~L}^{-1}$ and $0.028 \mathrm{~L}^{-1}$, and $5.2 \mathrm{~h}^{-1}, 3.6 \mathrm{~h}^{-1}$ and $3.2 \mathrm{~h}^{-1}$ for $P$. lima, $A$. minutum and $H$. triquetra microfiltration respectively. SEM analyses and internal fouling indexes allowed to conclude with an irreversible fouling attributed to fine particles (such as cell fragments) and dissolved organic compound. Besides, in the next study, longitudinal cuts of pores could be observed using SEM in order to better understand the structure and the organisation of internal fouling. For $H$. triquetra microfiltration, hydrophilicity increase is measured by contact angle after the operation. This is consistent with a fouling from biologic organic matter such as EPS.

Cake filtration phenomena occurred for each microfiltration after internal fouling; CFI equal to $11.4 \mathrm{~s} / \mathrm{L}^{2}, 10.3 \mathrm{~s} / \mathrm{L}^{2}$ and $2.5 \mathrm{~s} / \mathrm{L}^{2}$ for $P$. lima, $A$. minutum and $H$. triquetra microfiltration respectively. Cake filtration is mainly responsible for reversible fouling and it is all the more significant as TSS and DOC load is high. Cell size of micro-algae is not the only factor influencing cake resistance, and it appears that dissolved organic substances, fines and particulate size distribution are important factors affecting cake layer permeability. 
Microfiltration with 1,000 cells $/ \mathrm{mL}$ of $A$. minutum has also been carried out. No cake filtration phenomenon is identified during the filtration time (180 minutes). Only pore blocking and pore constriction occur and irreversible fouling is responsible for $72 \%$ of flux decline. In order to observe a cake filtration with weak concentration of microalgae, filtration time could be prolonged for several days, but the rise of gel formation will increase with filtration time.

In each case, cleaning procedure was efficient and initial permeability was recovered. The present approach allows to identify fouling mechanisms predominant during MF just from filtration time and volume filtered. With this approach, it will be easier to adapt and adjust a pretreatment before a membrane microfiltration process for industrial suspensions such as those found in aquaculture and to optimize the main parameters of control of the process (backwash and bubbling parameters, transmembrane pressure and cleaning procedure).

For a given micro-algae concentration (30,000 Cells $/ \mathrm{mL}$ in our case), the filtration behaviour and fouling behaviour can be very different based on the micro-algal species. In order to confirm these initial findings, a pilot scale system operating in steady state condition for several weeks/month should be set up. Also, in order to improve and complete the approach of fouling indexes and autopsy analytical tools, modelling membrane mass transfer could be used in the next study.

Moreover, since low hydrodynamic shear limits the destruction of micro-algal cells and exudation, hollow fiber microfiltration membranes present a good potential for the total removal of toxic micro-algae and could be considered in order to supply semi-closed and recirculating aquaculture systems with low-energy-consuming (around $0.1 \mathrm{kWh} / \mathrm{m}^{3}$ ).

\section{Acknowlegements}

This study is supported by two French research programmes (i) GERRICO "Gestion globale des ressources marines et des risques dans les espaces côtiers", a collaborating programme between Nantes University and Ifremer and supported by Region Pays de la Loire; and (ii) COMSAUMOL "Maintien de la commercialisation par la sauvegarde et la détoxification des mollusques", a collaborative programme between Ifremer and Nantes University funded by five French administrative Regions.

Furthermore, the authors wish to thank Claire Marcaillou, Patrick Lassus, Jerôme Hussenot, Philippe Truquet, Michèle Bardouil, Mathias Papin from Ifremer, and Romain Mallet (SCIAM, Angers University) for their participation. Also thank to N. Hearn (KRUSS GmBh, Hambourg Deutchland) for help in contact angles measurements.

\section{References}

[1] G.M. Hallegraeff, Marine Ecology Progress Series, 168 (1998) 297-309.

[2] S.-H. Kim, G.-T. Kim, S.-K. Yim, K.-H. Choi, C.-H. Yoon, K.-H. Choo, and S.-J. Choi, Desalination, 144 (1-3) (2002) 361-365.

[3] K.G. Sellner, G.J. Doucette, and G.J. Kirkpatrick, Journal of Industrial Microbiology and Biotechnology, 30 (2003) 383-404.

[4] S.-H. Kim and J.-S. Yoon, Desalination, 182 (1-3) (2005) 315-321.

[5] M. Petry, M.A. Sanz, C. Langlais, V. Bonnelye, J.-P. Durand, D. Guevara, W.M. Nardes, and C.H. Saemi, Desalination, 203 (1-3) (2007) 141-152.

[6] D.A. Caron, M.-E. Garneau, E. Seubert, M.D.A. Howard, L. Darjany, A. Schnetzer, I. Cetinic, G. Filteau, P. Lauri, B. Jones, and S. Trussell, Water Research, 44 (2) (2010) 385-416.

[7] S.M. Etheridge, Toxicon, 56 (2) (2010) 108-122. 
[8] P. Jaouen, B. Lépine, N. Rossignol, R. Royer, and F. Quéméneur, Biotechnology Techniques, 13 (1999) 877-881.

[9] O. Morineau-Thomas, P. Legentilhomme, P. Jaouen, B. Lépine, and Y. Rincé, Biotechnology Letters, 23 (2001) 1539-1545.

[10] N. Rossi, M. Derouiniot-Chaplain, P. Jaouen, P. Legentilhomme, and I. Petit, Bioresource Technology, 99 (14) (2008) 6162-6167.

[11] N. Rossi, P. Jaouen, P. Legentilhomme, and I. Petit, Food and Bioproducts Processing, 82 (3) (2004) 244-250.

[12] N. Rossi, I. Petit, P. Jaouen, P. Legentilhomme, and M. Derouiniot, Separation Science and Technology, 40 (2005) 3033-3050.

[13] N. Rossignol, P. Jaouen, J.-M. Robert, and F. Quéméneur, Bioresource Technology, 73 (2) (2000) 197-200.

[14] N. Rossignol, T. Lebeau, P. Jaouen, and J.M. Robert, Bioprocess Engineering, 23 (2000) 495-501.

[15] N. Rossignol, L. Vandanjon, P. Jaouen, and F. Quéméneur, Aquacultural Engineering, 20 (3) (1999) 191-208.

[16] L. Vandanjon, P. Jaouen, N. Rossignol, F. Quéméneur, and J.M. Robert, Journal of Biotechnology, 70 (1-3) (1999) 393-402.

[17] J.B. Castaing, A. Massé, M. Pontié, V. Séchet, J. Haure, and P. Jaouen, Desalination, 253 (1-3) (2010) 71-77.

[18] D.A. Ladner, D.R. Vardon, and M.M. Clark, Journal of Membrane Science, 356 (1-2) (2010) 33-43.

[19] Y.-T. Chiou, M.-L. Hsieh, and H.-H. Yeh, Desalination, 250 (2) (2010) 648-652.

[20] M. Spérandio, A. Massé, M.C. Espinosa-Bouchot, and C. Cabassud, Water science \& technology, 52 (10-11) (2005) 401-408.

[21] A. Massé, M. Spérandio, and C. Cabassud, Water Research, 40 (12) (2006) 24052415.

[22] F. Quéméneur, P. Jaouen, J.P. Maleriat, J.P. Schlumpf, L. Bon, and E. Lebegue, Revue des sciences de l'eau (Journal of Water Science), 14 (1) (2001) 21-34.

[23] R.C. Viadero and J.A. Noblet, Aquacultural Engineering, 26 (3) (2002) 151-169.

[24] T. Pulefou, V. Jegatheesan, C. Steicke, and S.-H. Kim, Desalination, 221 (1-3) (2008) 534-542.

[25] C. Visvanathan, N.Q. Hung, and V. Jegatheesan, Process Biochemistry, 43 (6) (2008) 673-682.

[26] C. Visvanathan, N. Boonthanon, A. Sathasivan, and V. Jegatheesan, Desalination, 153 (1-3) (2003) 133-140.

[27] O. Lorain, B. Hersant, F. Persin, A. Grasmick, N. Brunard, and J.M. Espenan, Desalination, 203 (1-3) (2007) 277-285.

[28] M.J. Sharrer, K. Rishel, and S.T. Summerfelt, Bioresource Technology, 101 (12) (2010) 4322-4330.

[29] B.-B. Choi, Y.-J. Choi, J.-S. Choi, S. Lee, and H.-J. Oh, Desalination, 247 (1-3) (2009) 233-238.

[30] G. Di Profio, X. Ji, E. Curcio, and E. Drioli, Desalination, In Press, Corrected Proof

[31] G. Di Profio, X. Ji, E. Curcio, and E. Drioli, Workshop "Membrane Technologies for alternative Water Resources", Session 4 (2009) 77-81.

[32] Y. Ye, L.N. Sim, B. Herulah, V. Chen, and A.G. Fane, Journal of Membrane Science, 365 (1-2) (2010) 78-88.

[33] S.-H. Yoon, H.-S. Kim, and I.-T. Yeom, Journal of Membrane Science, 234 (1-2) (2004) 147-156.

[34] A.G. Fane, A. Yeo, A. Law, K. Parameshwaran, F. Wicaksana, and V. Chen, Desalination, 185 (1-3) (2005) 159-165.

[35] E.K. Lee, V. Chen, and A.G. Fane, Desalination, 218 (1-3) (2008) 257-270.

[36] S. Babel and S. Takizawa, Desalination, 261 (1-2) (2010) 46-51.

[37] A. Drews, C.-H. Lee, and M. Kraume, Desalination, 200 (1-3) (2006) 186-188.

[38] L. Barillé, J. Haure, E. Pales-Espinosa, and M. Morançais, Aquaculture, 217 (1-4) (2003) 501-514. 
[39] V. Jegatheesan, C. Zeng, L. Shu, C. Manicom, and C. Steicke, Journal of Cleaner Production, 15 (16) (2007) 1535-1544.

[40] T. Lindholm and C. Nummelin, Hydrobiologia, 393 (1999) 245-251.

[41] G.C. Pitcher, A.D. Cembella, L.B. Joyce, J. Larsen, T.A. Probyn, and C. Ruiz Sebastián, Harmful Algae, 6 (6) (2007) 823-836.

[42] C. Labry, E. Erard-Le Denn, A. Chapelle, J. Fauchot, A. Youenou, M.P. Crassous, J. Le Grand, and B. Lorgeoux, Journal of Experimental Marine Biology and Ecology, 358 (2) (2008) 124-135.

[43] P.H. Hermans and H.L. Bredée, Journal of Society of Chemical Industry, 55 (1936) 14.

[44] J. Hermia, Institut of Chemical Engineers, 60 (1982) 183.

[45] J.C. Schippers and J. Verdouw, Desalination, 32 (1980) 137-148.

[46] S.F.E. Boerlage, M. Kennedy, Z. Tarawneh, R. De Faber, and J.C. Schippers, Desalination, 161 (2) (2004) 103-113.

[47] M. Pontié, S. Rapenne, A. Thekkedath, J. Duchesne, V. Jacquemet, J. Leparc, and H. Suty, Desalination, 181 (1-3) (2005) 75-90.

[48] K. Kecili, H. Habarou, H. Suty, J.-P. Croué, and M. Pontié, Comptes Rendus Chimie, 9 (9) (2006) 1178-1191.

[49] ASTM, D 4189-95 ASTM, (1995).

[50] E. Brauns, E. Van Hoof, B. Molenberghs, C. Dotremont, W. Doyen, and R. Leysen, Desalination, 150 (1) (2002) 31-43.

[51] P. Lipp, B. Görge, and R. Gimbel, Desalination, 79 (2-3) (1990) 203-216.

[52] C. Park, H. Kim, S. Hong, and S.-I. Choi, Journal of Membrane Science, 284 (1-2) (2006) 248-254.

[53] S.G. Yiantsios and A.J. Karabelas, Desalination, 151 (3) (2003) 229-238.

[54] S.G. Yiantsios, D. Sioutopoulos, and A.J. Karabelas, Desalination, 183 (1-3) (2005) 257-272.

[55] A. Mosset, V. Bonnelye, M. Petry, and M.A. Sanz, Desalination, 222 (1-3) (2008) 1723.

[56] E.M. Tracey and R.H. Davis, Journal of Colloid and Interface Science, 167 (1) (1994) 104-116.

[57] A. Grenier, M. Meireles, P. Aimar, and P. Carvin, Chemical Engineering Research and Design, 86 (11) (2008) 1281-1293.

[58] S.M. Nascimento, D.A. Purdie, and S. Morris, Toxicon, 45 (5) (2005) 633-649.

[59] R.R.L. Guillard and J.H. Ruther, Canadian Journal of Microbiology, 8 (1962) 229-239.

[60] E. Balech, Phycolgia, 28 (2) (1989) 206-211.

[61] G. Hansen, N. Daugbjerg, and J.M. Franco, Harmful Algae, 2 (4) (2003) 317-335.

[62] R.R.L. Guillard and P.E. Hargraves, Phycologia, 32 (1993) 234-236.

[63] V. Séchet, G. Bougaran, P. Lablanc, M. Bohec, P. Truquet, M. Sibat, V. Savar, R. Kass, E. Lukomska, and Z. Amzil, Proceedings of the 13th International Conference on Harmful Algae, (2008) 121.

[64] P. Lassus, R. Baron, P. Garen, P. Truquet, P. Masselin, M. Bardouil, D. Leguay, and Z. Amzil, Aquatic Living Resources, 17 (2004) 207-214.

[65] M. Pontié, A. Thekkedath, K. Kecili, H. Habarou, H. Suty, and J.P. Croué, Desalination, 204 (1-3) (2007) 155-169.

[66] H.K. Shon, S. Vigneswaran, M.H. Zareie, R.B. Aim, E. Lee, J. Lee, J. Cho, and I.S. Kim, Desalination, 236 (1-3) (2009) 282-290.

[67] E.O. Mohamedou, M.-Y. Tang, A. Lebkiri, E.H. Rifi, S. Fernandez de la Puente Gonzalez, D.B. Penate Suarez, A.K. Ould Mahmoud, M. Lemine Fagel, P. Jaouen, and M. Pontié, Journal of Water Science, 23 (2) (2010) 147-158.

[68] G. Cauwet: K. Grasshoff, K. Kremling, and M. Ehrhardt, (Eds.), Methods of Seawater Analysis, WILEY-VCH, Weinheim. 1999, pp. 407-420.

[69] R. Sempéré and G. Cauwet, Estuarine, Coastal and Shelf Science, 40 (1) (1995) 105-114.

[70] S.C. Yoro, C. Panagiotopoulos, and R. Sempéré, Water Research, 33 (8) (1999) 1956-1959. 
[71] Y. Ye, P. Le Clech, V. Chen, A.G. Fane, and B. Jefferson, Desalination, 175 (1) (2005) 7-20.

[72] G. Belfort, R.H. Davis, and A.L. Zydney, Journal of Membrane Science, 96 (1-2) (1994) 1-58.

[73] C.-C. Ho and A.L. Zydney, Journal of Colloid and Interface Science, 232 (2) (2000) 389-399.

[74] S.F.E. Boerlage, M.D. Kennedy, M.R. Dickson, D.E.Y. El-Hodali, and J.C. Schippers, Journal of Membrane Science, 197 (1-2) (2002) 1-21.

[75] W. Yuan, A. Kocic, and A.L. Zydney, Journal of Membrane Science, 198 (1) (2002) 51-62.

[76] S. Bhattacharjee and H. Seungkwan, Korean Membrane Journal, 7 (1) (2005) 1-18.

[77] K.-J. Hwang, C.-Y. Liao, and K.-L. Tung, Journal of Membrane Science, 287 (2) (2007) 287-293.

[78] F. Meng, H. Zhang, Y. Li, X. Zhang, and F. Yang, Journal of Membrane Science, 262 (1-2) (2005) 107-116.

[79] R. Wakeman, Separation and Purification Technology, 58 (2) (2007) 234-241.

[80] O. Morineau-Thomas, P. Jaouen, and P. Legentilhomme, Bioprocess and Biosystems Engineering, 25 (1) (2002) 35-42.

[81] M. Frappart, A. Massé, M.Y. Jaffrin, J. Pruvost, and P. Jaouen, Desalination, In Press, Corrected Proof (doi.org/10.1016/j.desal.2010.07.061) (2010)

[82] M. Kennedy, S.-M. Kim, I. Mutenyo, L. Broens, and J. Schippers, Desalination, 118 (1-3) (1998) 175-187.

[83] T. Kawakatsu, M. Nakajima, S.-i. Nakao, and S. Kimura, Desalination, 101 (3) (1995) 203-209.

[84] M. Nyström, K. Ruohomäki, and L. Kaipia, Desalination, 106 (1-3) (1996) 79-87.

[85] P. Jaouen, L. Vandanjon, and F. Quéméneur, Bioresource Technology, 68 (2) (1999) 149-154.

[86] L. Vandanjon, N. Rossignol, P. Jaouen, J.M. Robert, and F. Quéméneur, Biotechnology and Bioengineering, 63 (1) (1999) 1-9.

[87] C. Gaucher, P. Legentilhomme, P. Jaouen, and J. Comiti, Chemical Engineering Research and Design, 80 (1) (2002) 111-120.

[88] O. Morineau-Thomas, C. Lelièvre, N. Rossignol, P. Jaouen, and P. Legentilhomme, The Canadian Journal of Chemical Engineering, 78 (2000) 248-260.

[89] P. Velikovska, P. Legentilhomme, J. Comiti, and P. Jaouen, Journal of Membrane Science, 240 (1-2) (2004) 129-139.

\section{Tables}

Table 1 : Characteristics of MF membrane.

\begin{tabular}{lc}
\hline Internal diameter $(\mu \mathrm{m})$ & 700 \\
External diameter $(\mu \mathrm{m})$ & 1217 \\
Fiber length $(\mathrm{cm})$ & 9.5 \\
Roughness values $(\mathrm{Ra})(\mathrm{nm})$ (outside surface) $\left(50 \times 50 \mu \mathrm{m}^{2}\right)$ & $210 \pm 50$ \\
Surface area $\left(\mathrm{m}^{2}\right)$ & 0.37 \\
Contact angle of outside/ inside surfaces $\left(^{\circ}\right)$ & $28 \pm 5 / 32 \pm 11$ \\
Pure water permeability at $20^{\circ} \mathrm{C}\left(\mathrm{L} \cdot \mathrm{h}^{-1} \cdot \mathrm{m}^{-2} \cdot\right.$ bar $\left.^{-1}\right)$ & $511 \pm 62$ \\
\hline
\end{tabular}


Table 2 : Suspensions characteristics.

\begin{tabular}{lccc}
\hline & P. lima & A. minutum & H. triquetra \\
\hline Micro-algae concentration (cells/ mL) & $25,428 \pm 2,219$ & $29,504 \pm 2,900$ & $28,267 \pm 2,320$ \\
Micro-algae size $(\mu \mathrm{m})$ & $25-50$ & $15-30$ & $10-25$ \\
Total Suspended Solid (TSS) $(\mathrm{mg} / \mathrm{L})$ & $258.5 \pm 30.8$ & $47.2 \pm 4.8$ & $28.0 \pm 5.0$ \\
Salinity (g/ L) & $35.0 \pm 0.5$ & $35.0 \pm 0.5$ & $35.0 \pm 0.5$ \\
Turbidity (NTU) & $104.0 \pm 2.5$ & $7.6 \pm 0.5$ & $11.2 \pm 2.0$ \\
Total Organic Carbon (TOC) $(\mathrm{mgC} / \mathrm{L})$ & $>50$ & $14.2 \pm 1.3$ & $7.4 \pm 0.5$ \\
Dissolved Organic Carbon (DOC) $(\mathrm{mgC/L})$ & $22.7 \pm 3.0$ & $6.3 \pm 1.3$ & $3.3 \pm 0.2$ \\
\hline
\end{tabular}

Table 3 : Average rejection rate obtained during MF.

\begin{tabular}{lccc}
\hline Micro-algae species & P. lima & A. minutum & H. triquetra \\
\hline Micro-algae (\%) & $>99$ & $>99$ & $>99$ \\
Turbidity (\%) & $>99$ & $>98$ & $>98$ \\
Dissolved Organic Carbon (DOC) (\%) & $46 \pm 11$ & $22 \pm 13$ & $0 \pm 9$ \\
\hline
\end{tabular}

Table 4 : Fouling Indexes (PCI, $\mathrm{PBI}$ and $\mathrm{CFI})$ from linear regression of microfiltration data for each micro-algae suspension tested.

\begin{tabular}{lccc}
\hline & Prorocentrum lima & Alexandrium minutum & Heterocapsa triquetra \\
\hline $\mathrm{PCl}\left(\mathrm{L}^{-1}\right)$ & 0.055 & 0.028 & 0.028 \\
$\mathrm{PBI}\left(\mathrm{h}^{-1}\right)$ & 5.2 & 3.6 & 3.2 \\
$\mathrm{CFI}\left(\mathrm{s} / \mathrm{L}^{2}\right)$ & 11.4 & 10.3 & 3.5 \\
\hline
\end{tabular}

\section{Figures}

Figure 1. Scheme of a submerged membrane pilot plant.

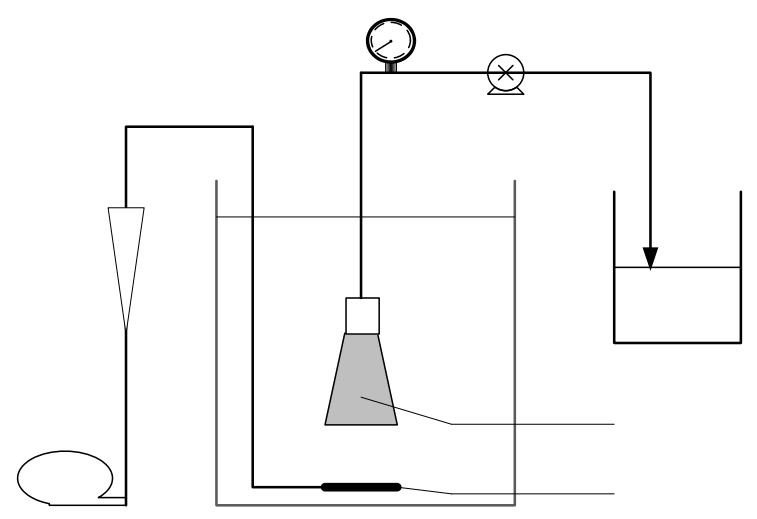


Figure 2. Particle size distributions of the three micro-algae.

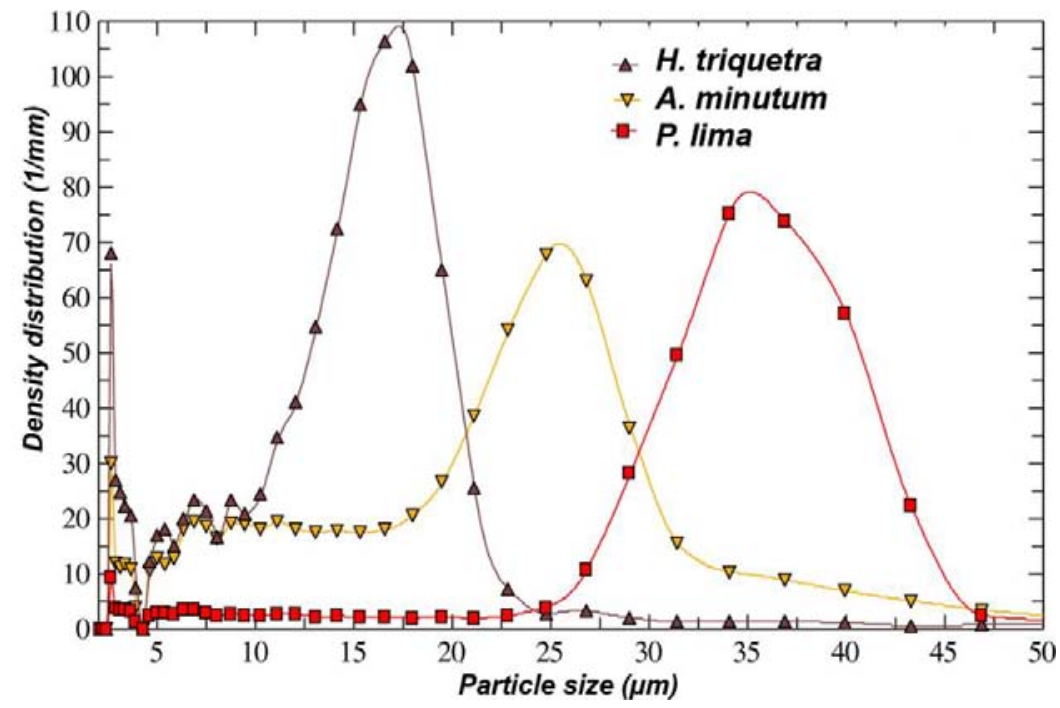

Figure 3. SEM images of micro-algae: from left to right, $H$. triquetra (CNRC-NRC ISBN 0660-96057-5), A. minutum (CNRS) and $P$. lima (Ifremer-Nantes university).
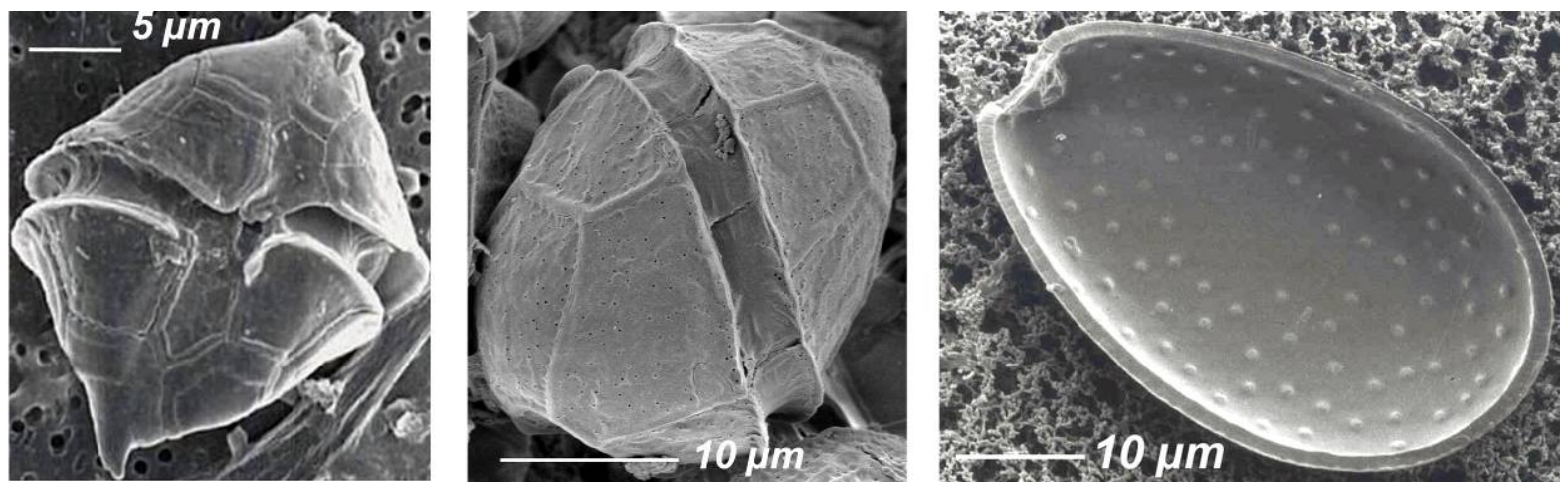

Figure 4. Relative permeate flux at $20^{\circ} \mathrm{C}$ vs time for each tested microfiltration in presence of the different micro-algae studied.

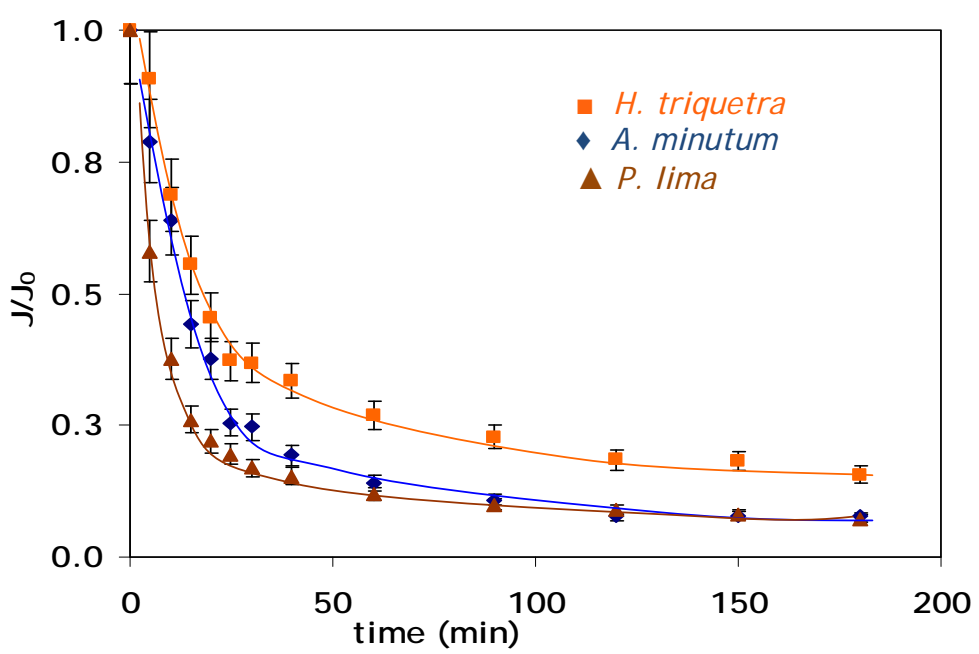


Figure 5. Fouling resistance $\left(R_{f}\right)$ of the MF membrane as a function of time for each MF filtration in presence of the three studied micro-algae.

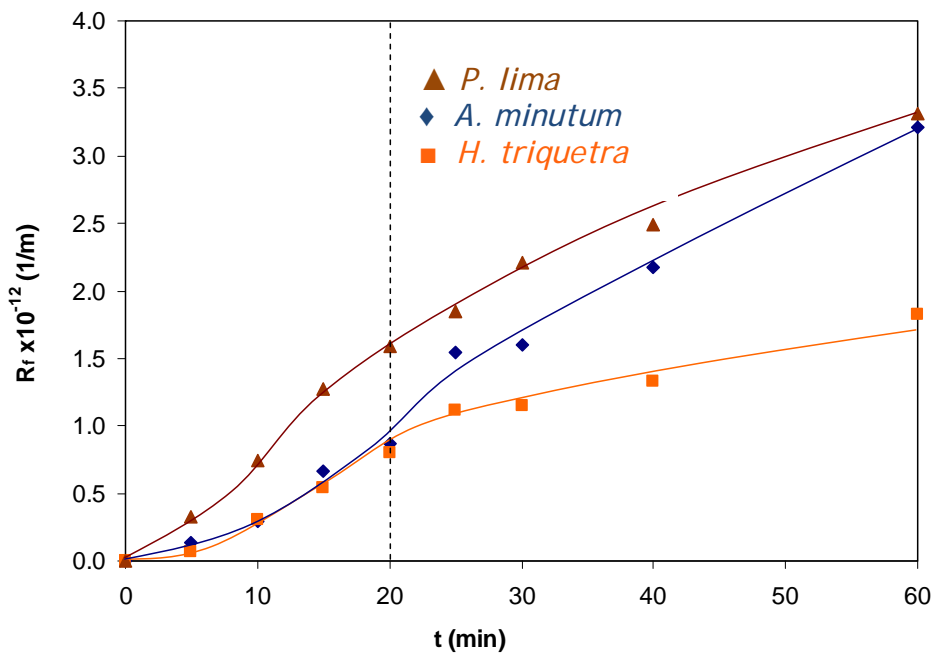

Figure $6 a$. A plot of permeate flow rate versus $V$ microfiltration curves - Pore Blocking Index (PBI) determination.

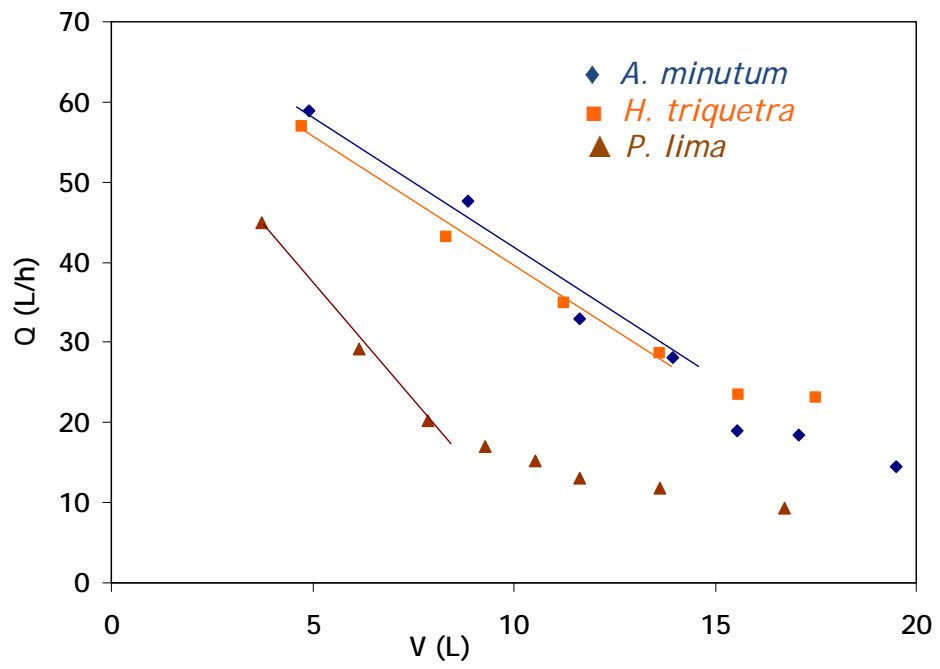

Figure 6b. A plot of $t / V$ versus $t$ microfiltration curves - Pore Constriction Index (PCl) determination.

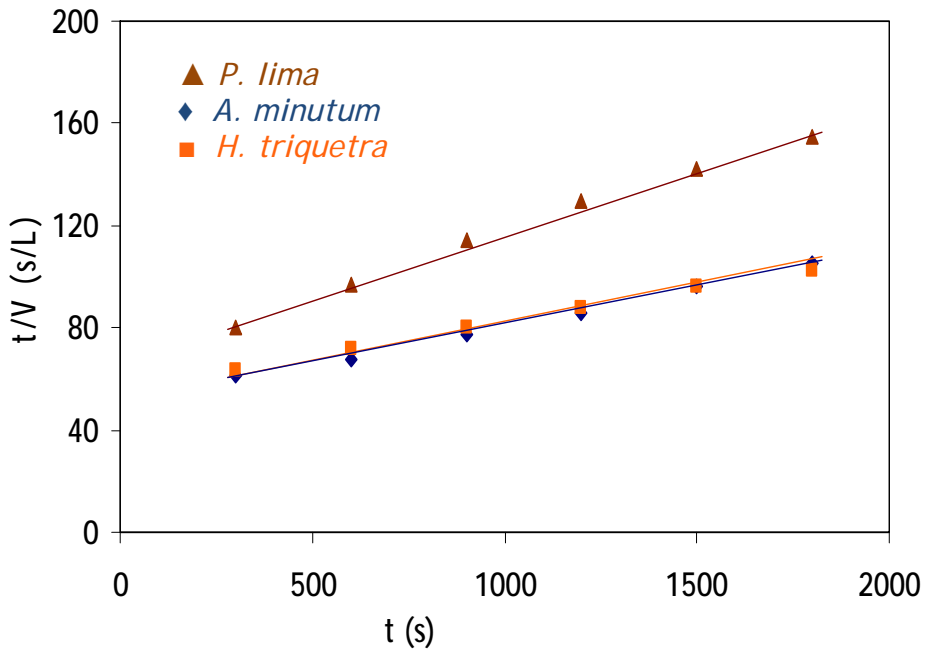


Figure 6c. A plot of $t / V$ versus $V$ microfiltration curves - Cake Filtration Index (CFI) determination.

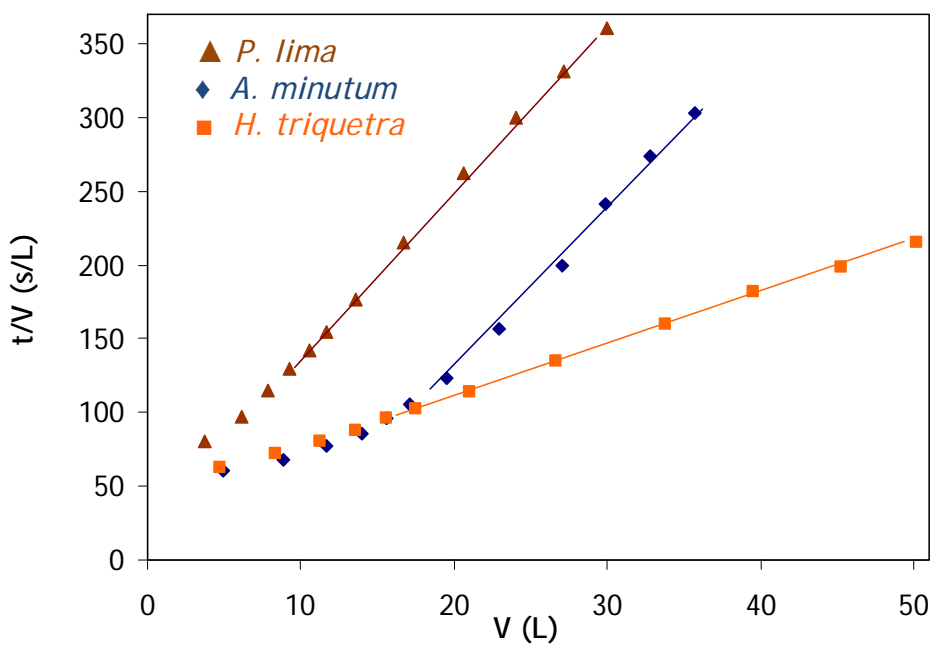

Figure 7. SEM image of clean MF membrane (external surface).

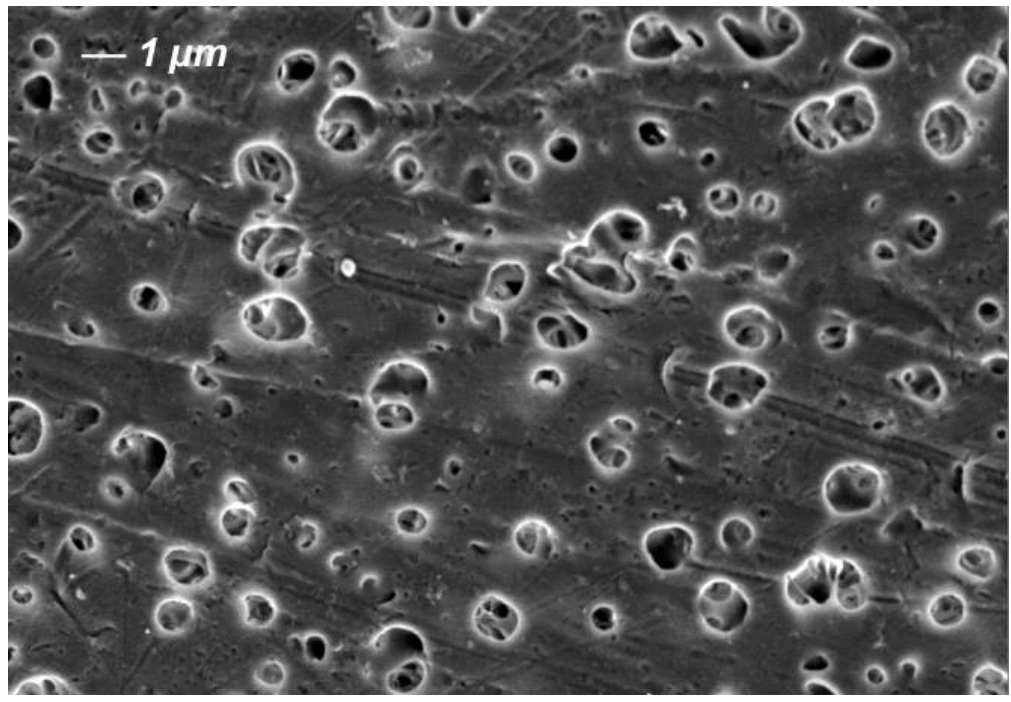


Figure 8. SEM images of external surface of fouled HF-MF membrane with $H$. triquetra suspension (a) and with $P$. lima filtration $(b)$.
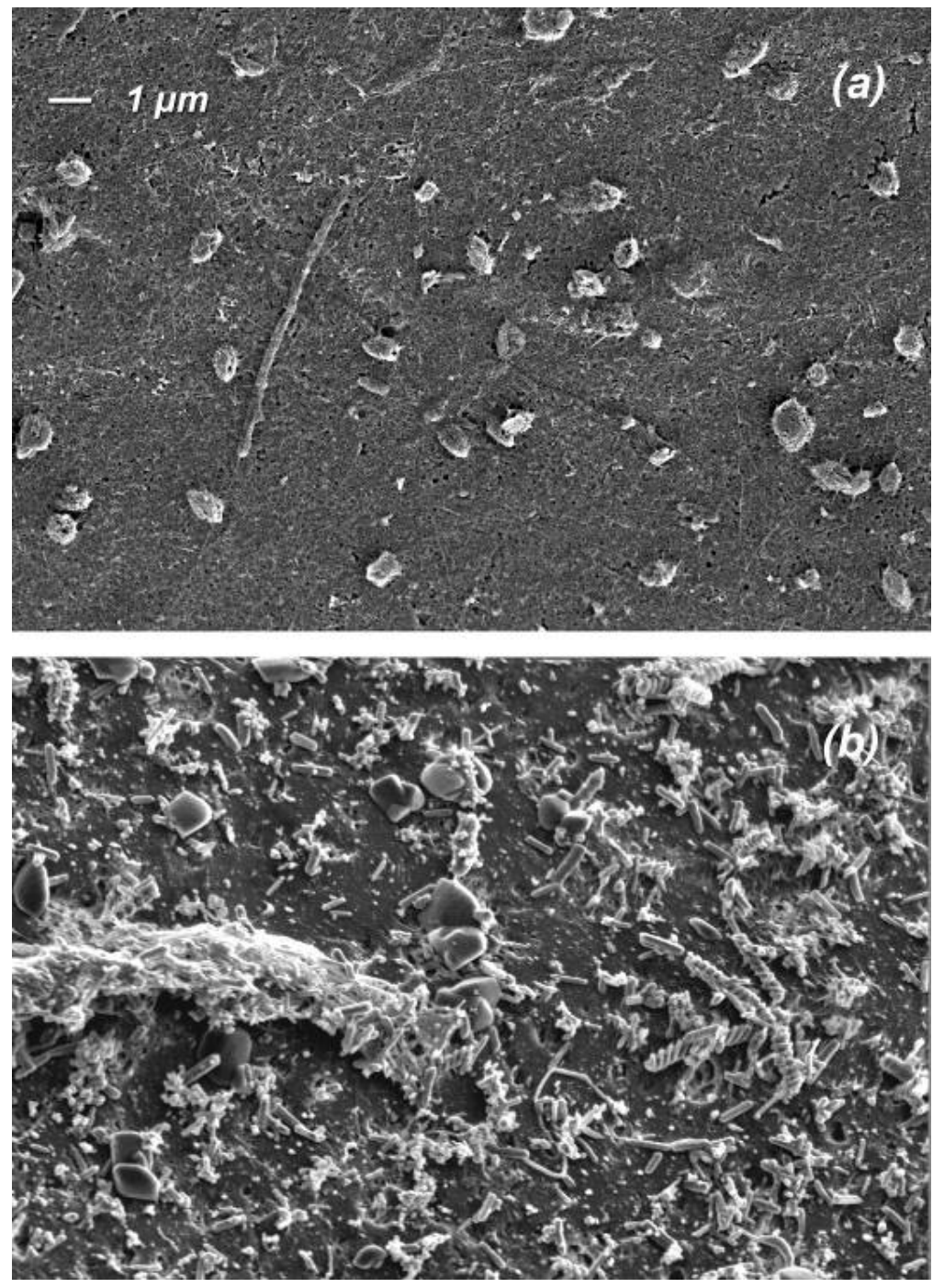
Figure 9. Schematic representation of standard and pore blocking models and cake filtration occurring during a membrane MF operation.

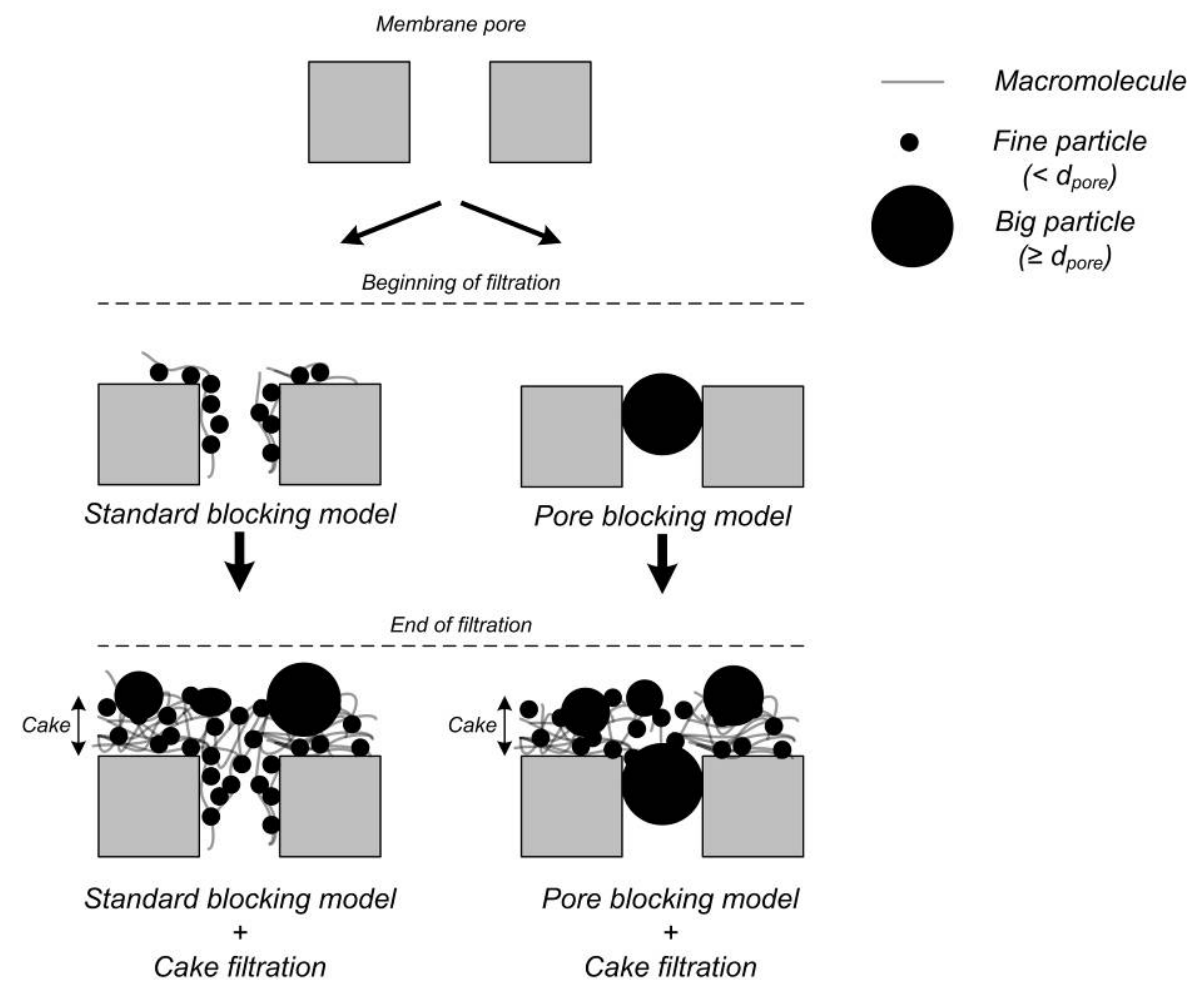

Figure 10. Relative permeate flow at $20^{\circ} \mathrm{C}$ versus time for $A$. minutum microfiltrations.

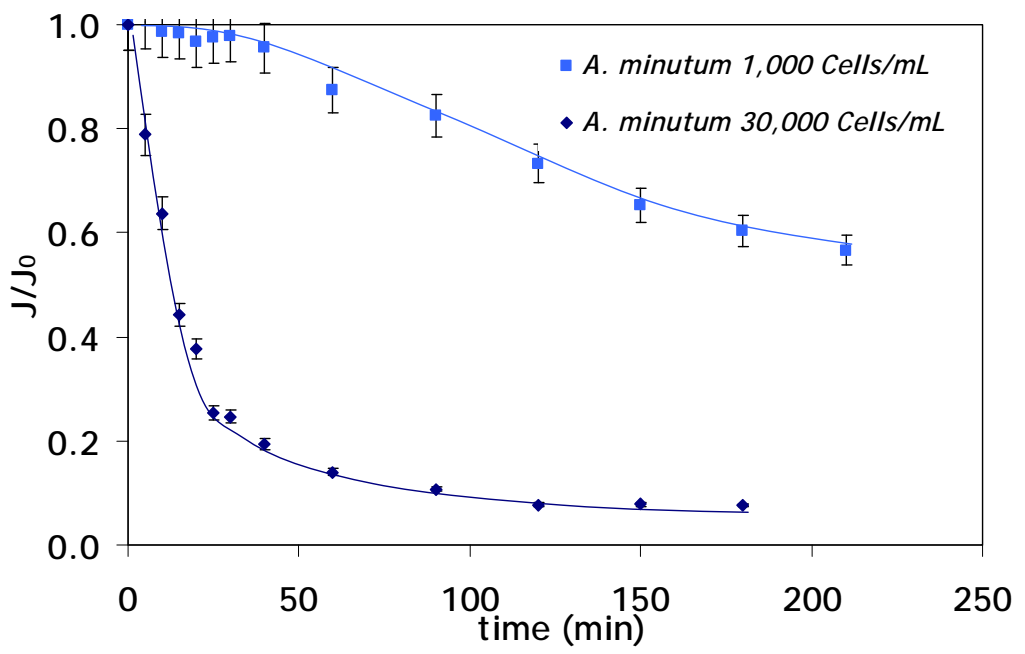


Figure 11. Fouling resistance (Rf) as a function of time for 1,000 Cells $/ \mathrm{mL}$ A. minutum microfiltration.

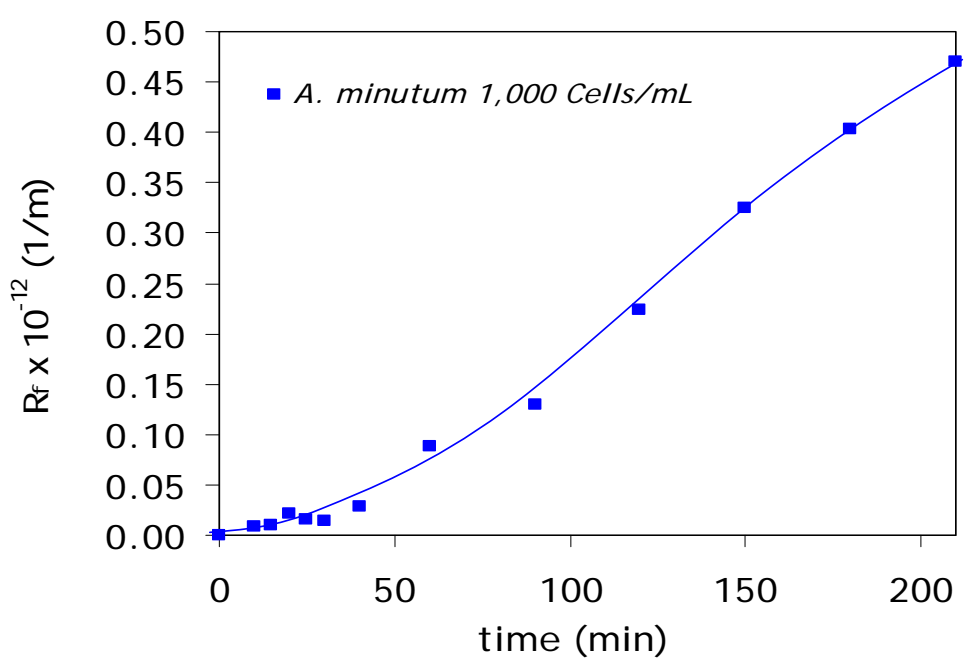

Figure 12. Pore Constriction Index (PCI) and Pore Blocking Index (PBI) determination for $A$. minutum MF for 1,000 and 30,000 cells $/ \mathrm{mL}$.
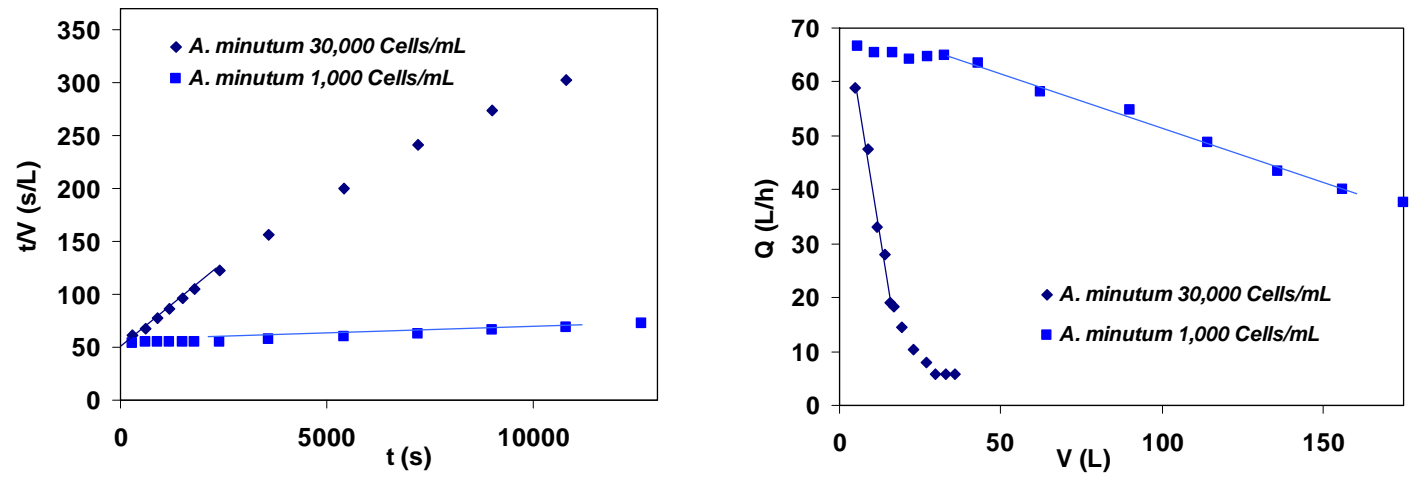